\title{
A COMPARATIVE STUDY ON E-LEARNING IMPLEMENTATION IN HIGHER EDUCATION IN RESPONSE TO THE COVID-19 PANDEMIC \\ Paula Dewanti ${ }^{1}$, Ni Putu Linda Santiari ${ }^{2}$, Kadek Vishnu Vedamurthi ${ }^{3}$ \\ 1,2,3 ITB STIKOM Bali \\ Email: pdewanti@gmail.com
}

\begin{abstract}
The aim of this study was to explore the use of distance learning in Indonesian universities during the pandemic. This was a continuation of previous research on the implementation of Digital Learning in several countries as an Emergency Response to the COVID-19 Pandemic. Given the uncertainty surrounding the end of the pandemic, as well as government regulations expanding the use of distance learning, researchers believe it is crucial to examine student attitudes toward implementation. In this study, the comparative study method was used to compare the similarities and differences between two or more properties and facts of the object under study based on a particular frame of mind. The findings indicate that there are similarities in the implementation of distance learning, which involves transforming face-to-face sessions in a classroom setting into live face-to-face sessions in virtual classrooms. The initiatives of each university are in line with government recommendations. The implementation, however, varies slightly due to differences in characteristics such as facility and infrastructure readiness that exist on each of these campuses. Further research focusing on Student Engagement and Student Experience, using larger data sets, would be expected to provide much more value and best practices for E-Learning implementation during the current COVID-19 pandemic.
\end{abstract}

\section{Keywords: Covid-19, e-learning, higher education.}

\section{INTRODUCTION}

\subsection{Introduction}

The technological age that is currently taking place has an impact on many fields, including the educational system (Collins \& Halverson, 2018). An educational paradigm has evolved in which information technology is used as a vehicle for scientific elaboration, either through the process of learning, academic, or research. Digital learning is one of the innovative learning techniques made possible by technology, or one of the effective learning practices that make use of technology (Blayone et al., 2017). However, technology does not completely replace human 
involvement, but rather assists humans in leveraging performance improvement of an effective learning process. Blended Learning, a combination of digital and traditional or classroom learning, has appeared as one of the solutions. According to Dwiyogo (2013), Blended Learning is an approach that mix, and combine, the strengths of the two methods, Face-to-Face and online learning. Blended Learning utilizes information technology in digital learning system which is the process of teaching and learning by utilizing information technology for the delivery of material, discussion and work on the problem anywhere and anytime without time limitation, by exploiting Internet (Luckin et al., 2012).

The Covid-19 pandemic has brought changes to the education system through the use of technology. The educational paradigm develops by placing information technology as a vehicle for developing science. During a pandemic, Face-to-Face sessions in conventional classrooms are transformed into Face-to-Face live-to-face sessions in virtual classrooms. This study was carried out to analyze the implementation performed by the selected universities on what was the best practice at the time this study was undertaken.

\section{E-Learning}

E-Learning have a lot of understanding about according to experts, some of which are: E-Learning is a type of teaching learning that allows the delivery of teaching materials to students by using internet, intranet and other computer network media (Harley, 2001), E-Learning is an educational system that uses electronic applications to support teaching and learning with internet media, computer network, and standalone computer (Glossary, 2001), and E-Learning as any learning using electronic circuits (LAN, WAN or Internet) content of learning, interaction and guidance (Dazki, 2015). Based on the above, the definition of E-Learning can be summed up as a learning and learning process that employs electronic information packages for learning and education purposes, which learners can access at any time and from any location using ICT. Furthermore, there are three functions, which are as an optional supplement, complement, or substitution.

a. Supplement

It is said to function as a supplement if learners have the option of using electronic learning materials or not. There is no obligation or requirement for learners to access electronic learning materials in this situation. While it is optional, learners who use it will definitely gain additional information or perspectives.

b. Complement

It is said to function as a complement (supplement) if the electronic learning materials are programmed to complete the learning materials received by students in the class (Lewis, 2002). In this case, complement means electronic learning material is programmed to become reinforcement material (enrichment) or remedial for learners in following conventional learning activity. Electronic learning materials are said to be enrichment, if the learners who can quickly master/understand the subject matter presented by the teacher in a Face-to-Face (fast leaners) are given the opportunity to access electronic learning materials that are specifically developed for them. The aim is to raise learners' mastery of the topic presented in the classroom by teachers. A remedial program is defined as one in which students who have difficulty understanding the subject matter presented by the teacher in Face-to-Face classes (slow learners) are given the opportunity to use electronic learning materials that are specifically tailored to them. 


\section{c. Substitution}

Some universities in developing countries are offering additional models of learning activities/lectures to their students. The goal is that students can flexibly manage their lecture activities in accordance with time and other activities of everyday students.

\section{Blended Learning}

In compared to Indonesia, Blended Learning has been used in the United States since 2005. Blended Learning has been defined as a formal or informal educational program that combines online digital media with traditional classroom methods. In this case, classroom time can be replaced or supplemented by an online learning experience, and students will learn about the same topic online as they do in class, where online and classroom learning seem to be parallel and complementary.

Blended Learning, also known as Hybrid Learning and Mixed-mode Learning, can vary in design and implementation. Blended Learning, for example, is carried out by focusing only on specific subjects or classes where there is a dominant learning model with traditional class methods (Dwiyogo, 2013).

Online learning can be a small component of traditional classroom-based learning. Lectures recorded via video, live video, and text chats, as well as other digitally activated learning activities that serve as the primary instructional interaction between Lecturers and students. In some cases, students can work independently on online materials, projects, and assignments at home or elsewhere; they just need to meet with Lecturers to review their learning progress, discuss their work, ask questions, or receive assistance with more difficult concepts. In other cases, students can devote their entire day to traditional classroom methods, but they will spend more time working online and independently than receiving instruction from a Lecturer. Aside from the mentioned above, there are numerous other possibilities.

\section{Blending with Google Apps}

Microsoft Office 365 was used to create the virtual classroom during the study. The researcher also disclosed that some Lecturers and students used the Google Classroom platform, as well as other Google Account affiliates. It demonstrates that Blended Learning can be regarded as a Learning Ecosystem. For a more in-depth survey, Google Form was also used.

\section{Blending with Mobile}

The use of WhatsApp Groups helps in the advancement of learning. After class, both the lecturer and the student will be able to communicate and be accessible for any discussion, question, or concern.

\section{Blending with Video}

Furthermore, mobile usage included video attachments for visual interaction and live demonstration. This could be a customized video or a public video related to an ongoing discussion.

\section{Open Blending and LMS}

Finally, the university's Learning Management System (LMS) as well as other platforms were used to promote sharing and collaboration.

\subsection{Research questions}

This research is focused on the following questions.

1) What are the initiatives of higher education institutions in response to the Ministry of Education and Culture's distance learning policy?

2) How is the daily learning process implemented in Indonesian universities in practice?

3) How effective is virtual learning during the ongoing Covid-19 pandemic? 


\subsection{Significance of the study}

The following is a description of the research roadmap: The first stage involves observing the initial position (which already exists), the second stage involves obtaining input (feedback) through correspondence and literature studies, and the third stage involves formulating the best practice as an internal constructive improvement. Based on the final results, it is hoped that it can be used as a reference material for Indonesian decision-makers to prepare for similar emergencies in the future.

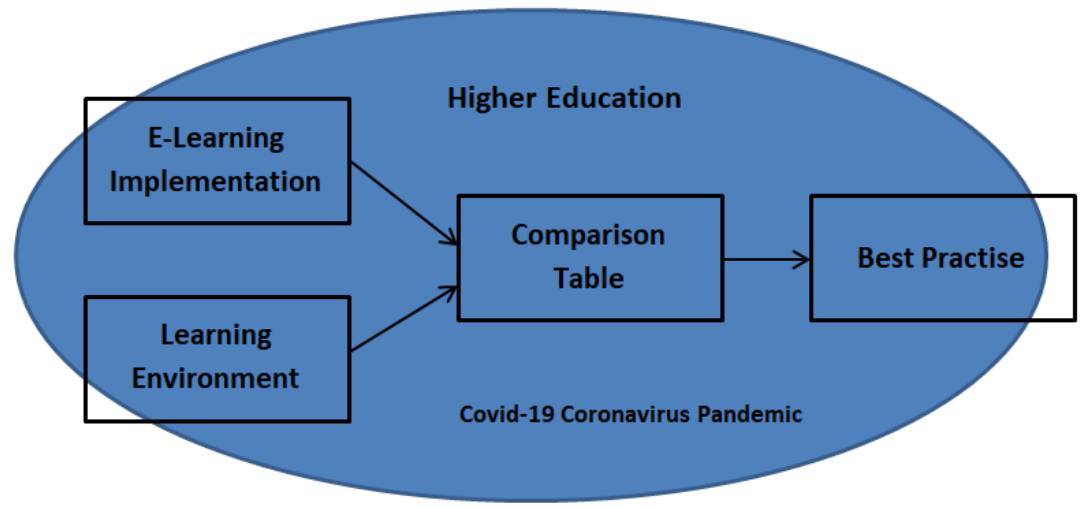

Figure 1. Research Framework (Dewanti, et al., 2021).

\section{METHOD}

\subsection{Research Design}

This research was done in the following stages:

a. Specify the Goal. The Research Problem, which has been framed to find an answer or solution to the problem at hand, guides the first step in the research flow.

b. Specify the Methodology. The second step is the Theoretical Framework, which involves researching research methods that will allow us to find appropriate methods to use in this study.

c. Literary Analysis. The third stage involves locating relevant literature to the research problem outlined in the study.

d. Data Collection. Purposive samplings were used to distribute questionnaires to correspondence resources.

e. Synthesis of Data Analysis. Identifying the data and depicting the findings

f. Recommendations and Conclusions. To write a summary of the findings.

\subsection{Participants}

Following the completion of the Literature Review stage, the next step is to collect data relevant to the object of research. Table 1 lists respondents' university of origin. 
Table 1. Respondents Data

\begin{tabular}{|c|c|c|}
\hline No. & University & Study Programs \\
\hline 1 & IAIN Palangkaraya & Islamic Communication \\
\hline \multirow[t]{2}{*}{2} & Politeknik Negeri Banjarmasin & Business Administration/Informatics \\
\hline & & Management \\
\hline 3 & Universitas Multimedia Nusantara & Engineering and Informatics \\
\hline 4 & Universitas Udayana & SAI \\
\hline 5 & Universitas Kristen Maranatha & Engineering \\
\hline 6 & STMIK Banjarbaru & Information Systems \\
\hline 7 & STMIK Lombok & Engineering and Informatics \\
\hline 8 & Universitas Teknologi Mataram & FTIK \\
\hline 9 & STMIK Palangkaraya & Information Systems \\
\hline 10 & Universitas Persada Indonesia YAI & Teknik \\
\hline 11 & STMIK Banjarbaru & Engineering and Informatics \\
\hline 12 & FKIP UMSU MEDAN & KIP \\
\hline 13 & STIKES Jayakarta & Nursing \\
\hline 14 & Unissula & Industrial Technology \\
\hline 15 & Universitas Khairun & Fisheries and Marine \\
\hline 16 & Universitas Bumigora & Engineering and Design \\
\hline 17 & Universitas Madura & Engineering \\
\hline 18 & Universitas Pasundan & Engineering \\
\hline 19 & Universitas Harapan Medan & Engineering and Computer \\
\hline 20 & Politeknik Negeri Banjarmasin & Informatics Management \\
\hline 21 & $\begin{array}{l}\text { Sekolah Tinggi Pariwisata } \\
\text { Mataram }\end{array}$ & Tourism \\
\hline 22 & UIN Alauddin Makassar & Islamic Economics and Business \\
\hline 23 & $\begin{array}{l}\text { STIKes Tri Mandiri Sakti } \\
\text { Bengkulu }\end{array}$ & Nursing \\
\hline 24 & Universitas Halu Oleo & Teacher Training and Education Science \\
\hline 25 & STIKes Binalita Sudama Medan & Nursing \\
\hline
\end{tabular}

At this stage, correspondence is sent to the respondents who have been determined to be the focus of this study. The data was gathered using a questionnaire that was distributed to the respondents. Respondents to the effectiveness questionnaire in the early stages of the study were Lecturers, who were then followed by students from lecturers at each campus that became the focus of this research.

\subsection{Instruments}

The questionnaire is divided into four sections and contains a total of 20 statements, including the following: Basic Demographics on Chart I; Chart II about the advantages and disadvantages of E-Learning; Chart III: Comparison of Face-to-Face Learning, E-Learning, and a 
Live-Face-to-Face Learning; and the closing statement in Chart IV is about the acceptance of learning through E-Learning during the pandemic.

\subsection{Data Analysis}

The Systematic Literature Review approach was used in this study to define a specific issue, compile published literature on a topic, summarize critical points of current knowledge about the problem, and suggest next steps in addressing it (Okoli \& Schabram, 2010). A literature review is a term that refers to the process of gathering, verifying, and (re)analyzing information from existing literature in order to answer a specific research question.

This research used comparative study to compare the similarities and differences of two or more properties and facts of the object under study based on a specific frame of mind. Data gathered from reference sources in accordance with the research topic. This information is classified and used as a reference to contact the contact person via correspondence.

\section{FINDINGS AND DISCUSSION}

\subsection{Findings}

During the Covid-19 pandemic, online learning has become an integral part of the learning process. The educational paradigm is evolving as a result of the use of information technology as a vehicle for scientific progress. Face-to-Face sessions in traditional classrooms are transformed into virtual classroom Face-to-Face sessions. The implementation of Digital Learning on each campus varies slightly due to differences in characteristics such as facility and infrastructure readiness that exist on each of these campuses. Prior to the pandemic, 76.7 percent of Lecturer respondents said they used E-Learning. Meanwhile, 23.3 percent of those polled said they had never done so. The student confirmed it, stating 71.7 and 28.3. Figures 2 and 3 indicate this.

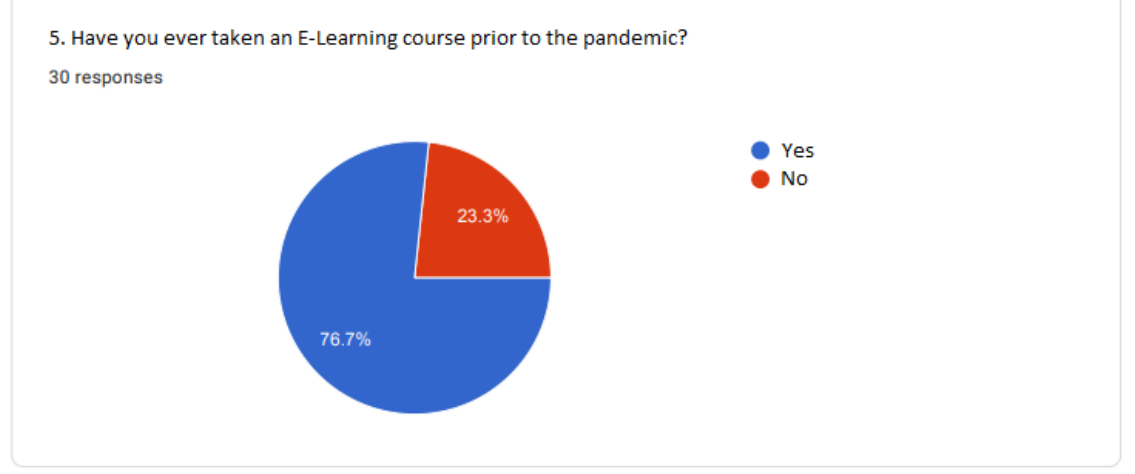

Figure 2. Usage E-Learning Before a Pandemic: Lecturers 
5. Have you ever taken an E-Learning course prior to the pandemic?

46 responses

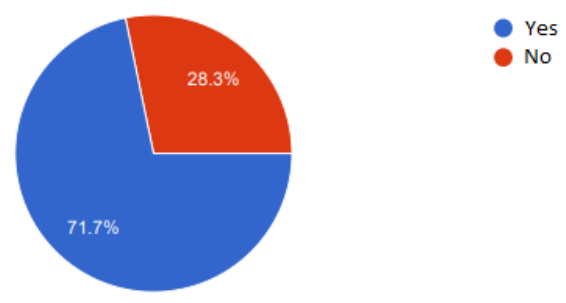

Figure 3. Usage E-Learning Before a Pandemic: Students

According to the questionnaire distribution, up to $60 \%$ of respondents stated that the learning process was implemented using a mixed method (Blended Learning). The new standard is to combine on-campus E-Learning with live face-to-face interactions via communication media such as Zoom, MS Teams, WebEx, Google Meet, Skype, and others. The use of only E-Learning was reported to be 16.7 percent, the same as the percentage for conventional Blended Learning via Face-to-Face and E-Learning. Learning is still primarily done in a classroom, according to 6.6 percent of those polled. Figure 4 shows respondents' responses to questions about the learning process's implementation on their respective campuses.

Lectures during the Covid-19 pandemic are carried out by: 30 responses

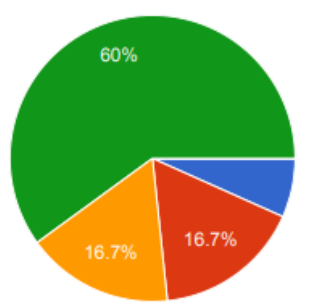

Conventional Face to Face

E-Learning

Blended Learning: Conventional Face to Face and E-Learning

Blended Learning: E-Learning as well as the Live-Face-to-Face platform(Zoom, MS Teams, WeBex, Google Meet, Skype, and others).

Others.

Lectures during the Covid-19 pandemic are carried out by:

46 responses

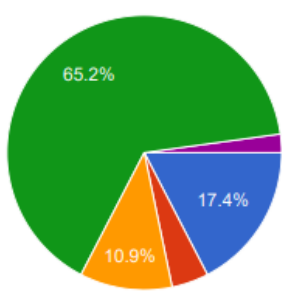

Conventional Face to Face

- E-Learning

Blended Learning: Conventional

Face to Face and E-Learning

Blended Learning: E-Learning as well as the Live-Face-to-Face platform(Zoom, MS Teams, WeBex, Google Meet, Skype, and others).

others.

Figure 4. Learning Process Implementation: Lecturers vs Students 
Student confirmed the use of a Blended Learning method by combining on-campus E-Learning with Face-to-Face interaction using communication media such as Zoom, MS Teams, WebEx, Google Meet, Skype, and others. The outcome is 65.2 percent.

Lecturers stated in Chart I on Basic Demographics that 10 percent of respondents have a high level of IT skills, same as the low one. Meanwhile, 80 percent of respondents said their IT skill level was moderate. From students' side, only 4.3 percent of respondents have a high level of IT skills. Meanwhile, 84.8 percent of respondents reported that their IT skill level was moderate, while 10.9 percent reported that it was low.

Figures 5 and 6 show how respondents responded to the statement in Chart I on Basic Demographics.

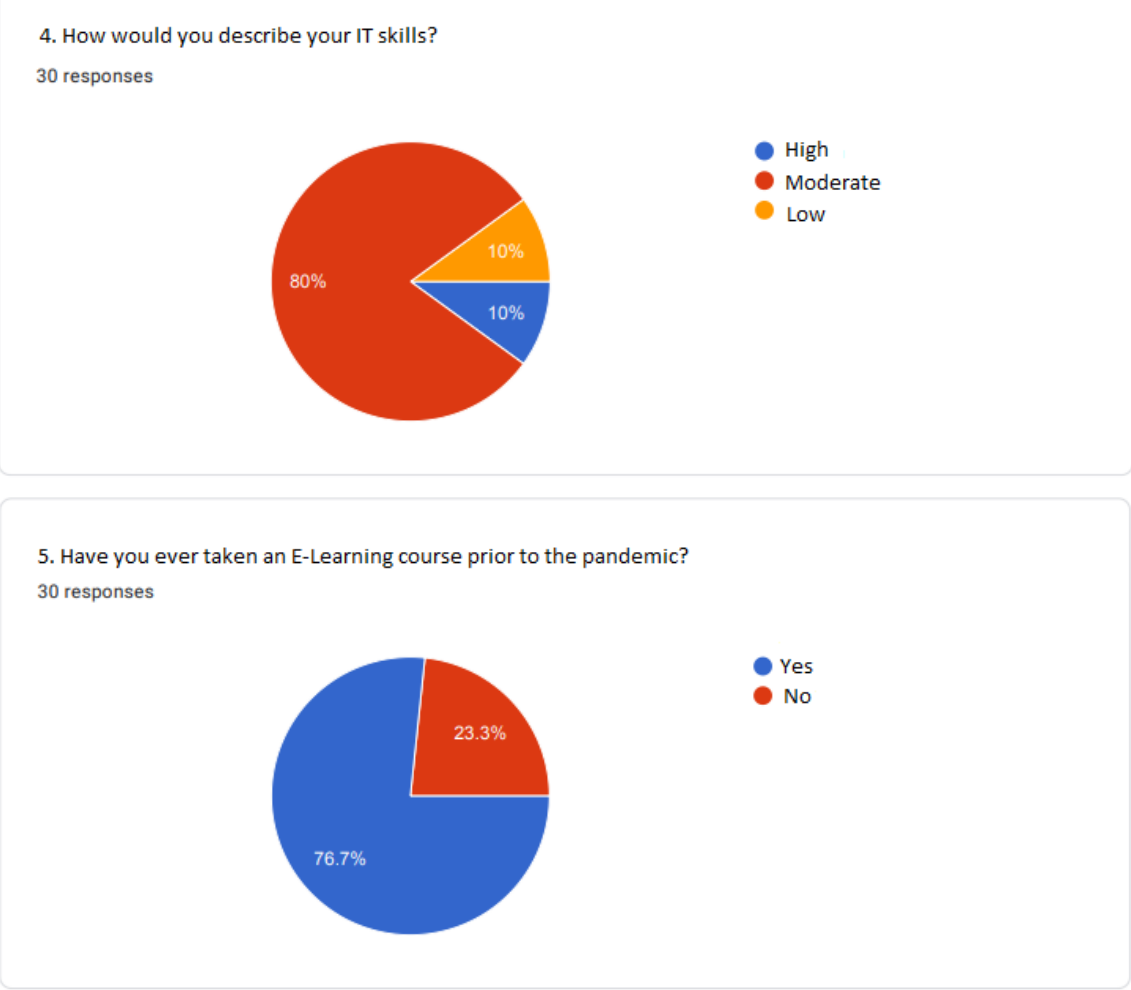

Figure 5. Basic Demographics - Lecturers 
4. How would you describe your IT skills?

46 responses

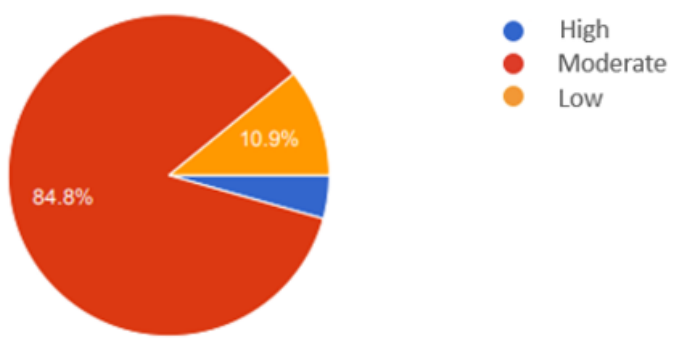

5. Have you ever taken an E-Learning course príor to the pandemic?

46 responses

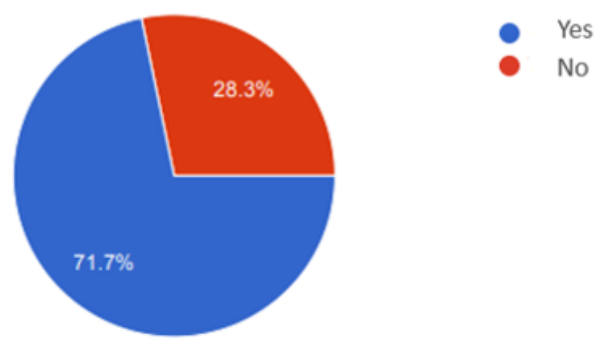

Figure 6. Basic Demographics - Students

It was further investigated with the Advantages and Disadvantages of E-Learning. The statement is enclosed in Table 2.

Table 2. The Advantages and Disadvantages of E-Learning's Statement

\begin{tabular}{lll}
\hline No. & \multicolumn{1}{c}{ Advantage } & \multicolumn{1}{c}{ Statement } \\
\hline \multicolumn{3}{c}{ Eis-advantage } \\
\hline 2 & Ease of access to online materials. & Less interaction with Lecturers. \\
\hline 3 & Learn at your own pace. & Technical problem. \\
& $\begin{array}{l}\text { Can be done from home or from } \\
\text { anywhere. }\end{array}$ & Lack of interaction among Students. \\
\hline 4 & Diverse class interactivity. & Unsupportive learning environment at \\
& & home or elsewhere. \\
\hline 5 & Ability to record each learning session. & Lack of self-discipline. \\
\hline 6 & Comfortable learning environment. & Less social interaction. \\
\hline 7 & Others. & Others. \\
\hline
\end{tabular}

Figure 7 and Figure 8 show respondents' responses to the statements in Chart II about the advantages and disadvantages of E-Learning. 


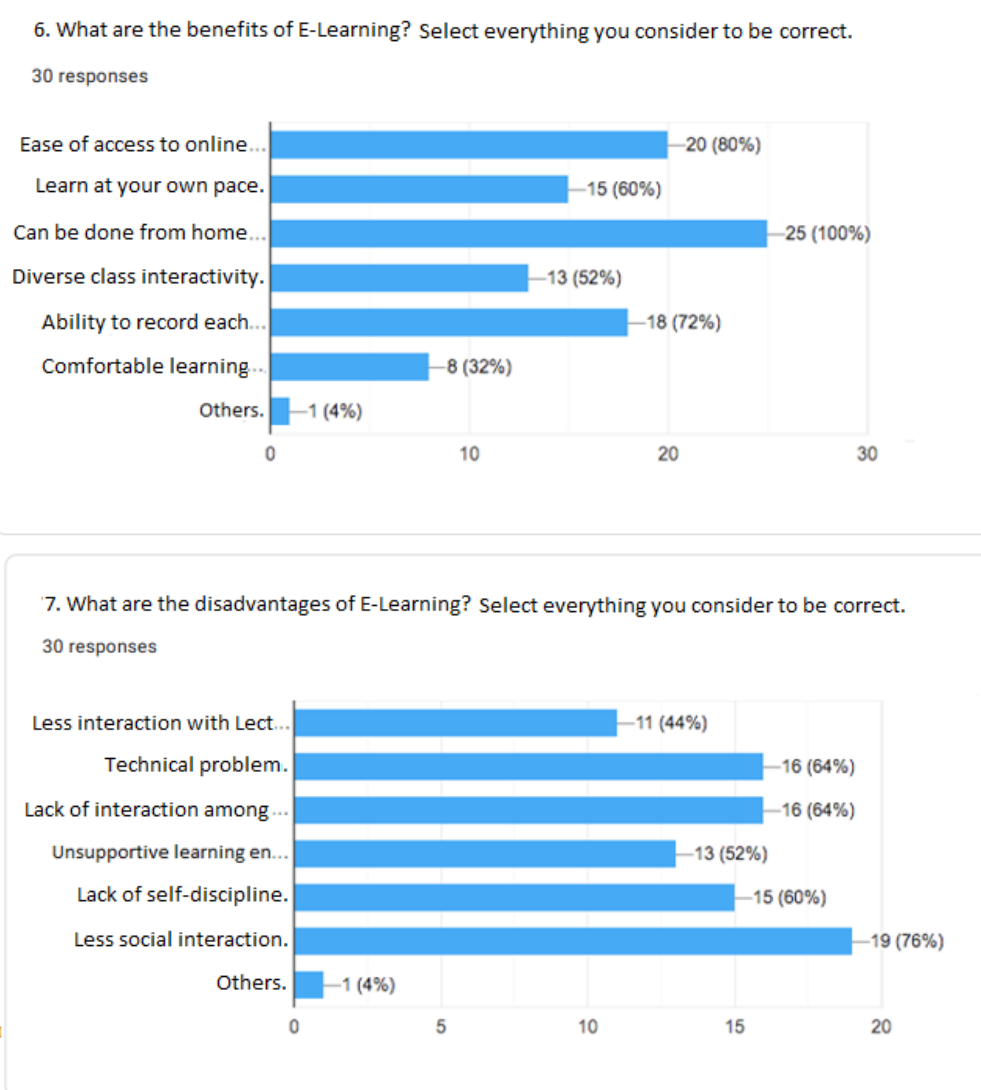

Figure 7. The Advantages and Dis-advantages of E-Learning - Lecturers
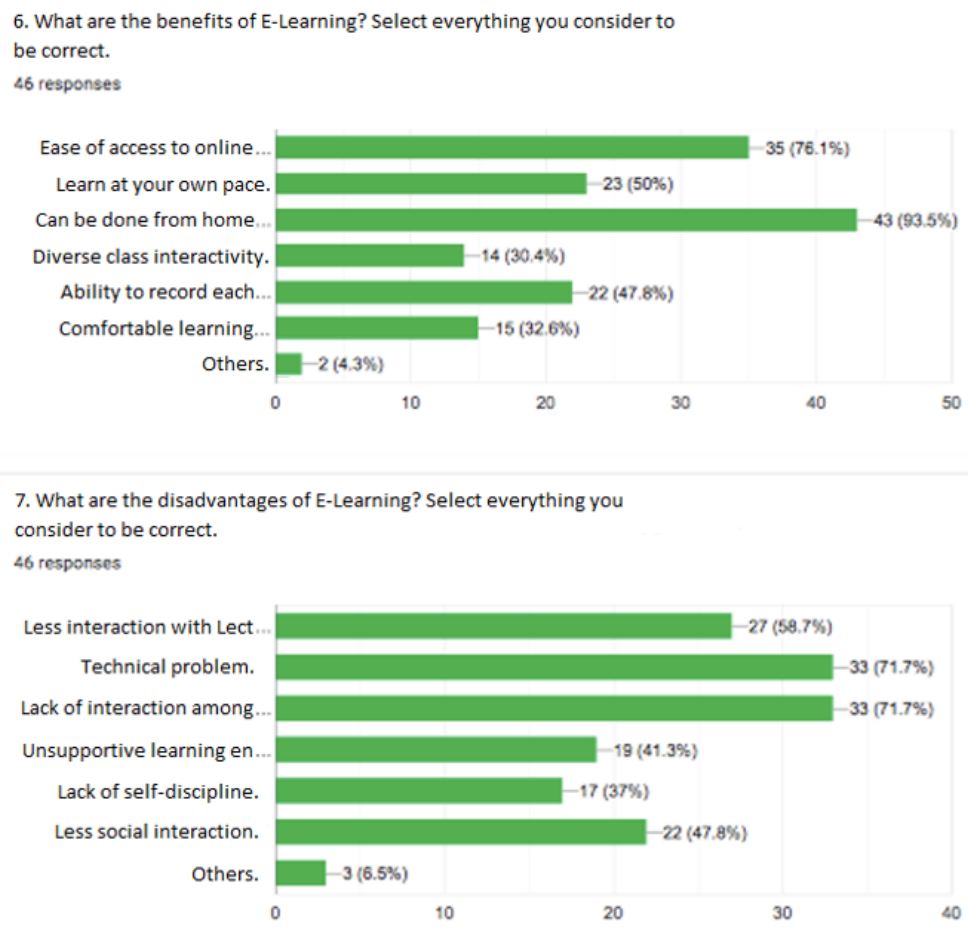

Figure 8. The Advantages and Dis-advantages of E-Learning - Students 
The highest percentage of the advantages of using E-Learning, according to the Lecturers, is "Can be done from home or from anywhere." with a total of $100 \%$ from Lecturer's side. The statement also received the highest percentage from students, with a 93.5\% voting in favor of it. Meanwhile, the statements 'Technical Problems' and 'Lack of Interaction Among Students.' have the highest percentage of disadvantage points in the use of E-Learning, with a score of $64 \%$ for Lecturers and 71.7 percent for Students.

Table 3 includes the following 12 statements from Chart III that compare Face-to-Face learning, E-Learning, and screen-to-screen learning in terms of mastery of the learning objectives: knowledge, practical skills, and competencies. Student activities during Face-to-Face learning, ELearning, and Face-to-Face learning platforms (Zoom, MS Teams, WebEx, Google Meet, Skype, and others).

\section{Table 3. Chart III: Comparison of Face-to-Face Learning, E-Learning, and Face-to-Screen Learning}

\begin{tabular}{|c|c|}
\hline & Statement \\
\hline \multicolumn{2}{|r|}{$\begin{array}{l}\text { Statements } 1-9 \text {, on a } 5 \text {-point scale (where } 1 \text {-very ineffective, to 5-very } \\
\text { effective). }\end{array}$} \\
\hline 1 & $\begin{array}{l}\text { Please rate E-Learning's effectiveness in delivering your learning } \\
\text { materials. }\end{array}$ \\
\hline 2 & $\begin{array}{l}\text { Please rate the effectiveness of E-Learning in terms of improving } \\
\text { the student's practical skills. }\end{array}$ \\
\hline 3 & $\begin{array}{l}\text { Please rate the efficacy of E-Learning in terms of increasing } \\
\text { student competence. }\end{array}$ \\
\hline 4 & $\begin{array}{l}\text { In terms of delivering your learning materials, please rate the } \\
\text { effectiveness of traditional Face-to-Face learning in the classroom } \\
\text { setting. }\end{array}$ \\
\hline 5 & $\begin{array}{l}\text { Please rate the effectiveness of traditional Face-to-Face learning in } \\
\text { classroom in terms of improving the practical skills of your } \\
\text { students. }\end{array}$ \\
\hline 6 & $\begin{array}{l}\text { Please rate the efficacy of traditional Face-to-Face learning in the } \\
\text { classroom setting in terms of increasing your students' competence. }\end{array}$ \\
\hline 7 & $\begin{array}{l}\text { Please rate the effectiveness of Face-to-Face learning platforms } \\
\text { (Zoom, MS Teams, WebEx, Google Meet, Skype, and others) for } \\
\text { delivering your learning materials. }\end{array}$ \\
\hline 8 & $\begin{array}{l}\text { Please rate the effectiveness of screen-based learning platforms } \\
\text { (Zoom, MS Teams, WebEx, Google Meet, Skype, and others) in } \\
\text { improving your students' practical skills. }\end{array}$ \\
\hline 9 & $\begin{array}{l}\text { Please rate the effectiveness of Face-to-Face learning platforms } \\
\text { (Zoom, MS Teams, WebEx, Google Meet, Skype, and others) in } \\
\text { terms of improving your students' competence. }\end{array}$ \\
\hline \multicolumn{2}{|r|}{$\begin{array}{l}\text { Meanwhile, a five-point scale is also used for statements } 10-12 \text {. (where } \\
1 \text {-very inactive, to 5-very active). }\end{array}$} \\
\hline
\end{tabular}


10 Please describe your students' E-Learning learning activities.

11 Please describe your student's activities in the classroom setting during traditional Face-to-Face learning.

12 Please describe your student's activities while using a screen-toscreen platform to learn (Zoom, MS Teams, WebEx, Google Meet, Skype, and others).

Figure 9 shows the findings of the closing statement, which is part of Chart IV relates to the acceptance of learning through E-Learning, during the pandemic, using a five-point scale (from 1-very unpleasant to 5-very pleasant). $3.3 \%$ of those who used E-Learning described it as extremely unpleasant, while 0 percent did not. $40 \%$ of Lecturers stated it was pleasant, and $20 \%$ said it was very pleasant. From the perspective of students, 6.5 percent of those who used ELearning found it extremely unpleasant, while 4.3 percent did not. $39.1 \%$ of students said it was pleasant, and $15.2 \%$ said it was very pleasant.

From the perspective of students, 6.5 percent of those who used E-Learning found it extremely unpleasant, while 4.3 percent did not. $39.1 \%$ of students said it was pleasant, and $15.2 \%$ said it was very pleasant.
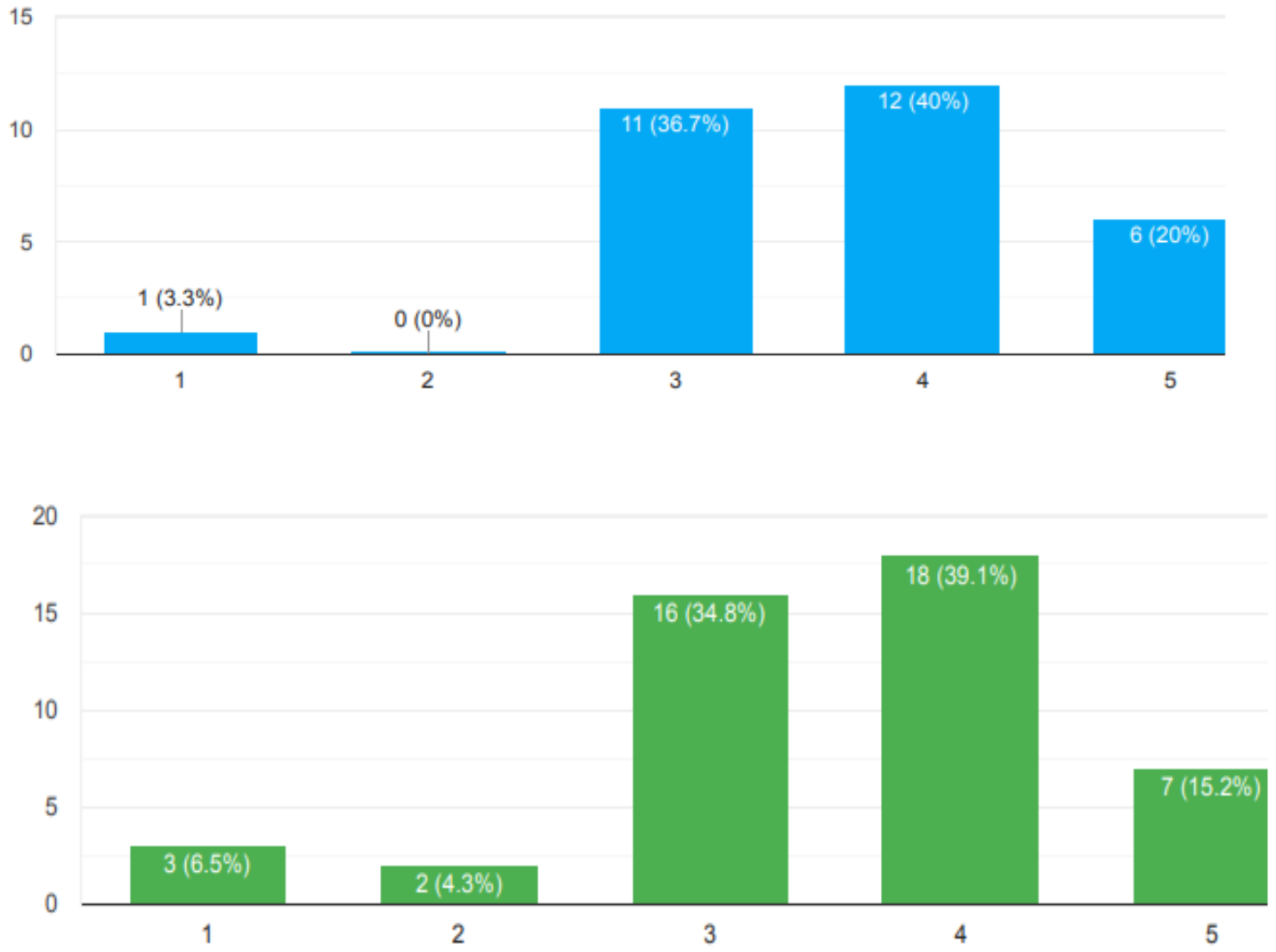

Figure 9. E-Learning Acceptance: Lecturers vs Students

\subsection{Discussion}

Prior to the Covid-19 pandemic, $76.7 \%$ of Lecturers reported that the E-Learning was in place on their campus. Meanwhile, 23.3 percent said they had never done so. It was confirmed by 
the student, who stated 71.7 and 28.3. Based on the IT skills, the average respondents claimed their level of IT expertise was moderate. According to Maphalala and Adigun (2021), academics believed that e-learning had a significant impact on improving students' academic performance. They did, however, mention that students' success would undoubtedly improve if technical support and training were made available on a regular basis.

Responses to the statements in Chart II about the advantages and disadvantages of ELearning revealed that one of the benefits of using E-Learning is that it can be done from home or anywhere. Meanwhile, technical issues and a lack of interaction consideration for the most of disadvantages in the use of E-Learning. Zboun and Farrah (2021) on their study stated that the most challenging aspects of online learning are poor internet connectivity, poor interaction, low motivation, low participation, and low understanding. They do, however, find online classes to be convenient, easy to access, and simple to review for exams.

Based on the results of Chart IV, which relates to the acceptance of learning through ELearning during the pandemic, it is reasonable to conclude that the implementation of E-Learning during the pandemic was pleasant. Yulmezi and Arifmiboy (2021) discovered that during the Covid-19 pandemic, students' satisfaction in the learning process strategy is quite satisfied, ranging from $40 \%$ to $70 \%$.

\section{CONCLUSIONS}

\subsection{Conclusion}

Initial findings from lecturers indicate that digital learning is an alternative option that is being implemented as part of the education sector's emergency plan in response to the COVID-19 pandemic. The institutions' initiatives in response to the Ministry of Education and Culture's distance learning policy were indeed consistent. The learning process done by blended learning and transforming Face-to-Face sessions in traditional classrooms into a Live-Face-to-Face sessions in virtual classrooms, in addition to the E-Learning. However, due to differences in characteristics such as facility and infrastructure readiness that exist on each of these campuses, the implementation on each campus varies slightly. More research is required to ensure student acceptance of E-Learning during the pandemic.

\subsection{Suggestions}

This study was performed prior to the newly announced variant Omicron. Along the way, there have been major advances with extra added initiatives. Given the virus's recent growth, increasing levels of virus exposure, and uncertainty surrounding the end of this pandemic, further research with larger datasets would be required, with a focus on Student Engagement and Student Experience, expected to provide more value and best practices for E-Learning implementation during the current COVID-19 pandemic.

\section{Acknowledgments}

This research was supported by the Institute of Technology and Business (ITB) STIKOM Bali's 2021 Internal Research Program.

\section{REFERENCES}


Blayone, T. J., Barber, W., DiGiuseppe, M., \& Childs, E. (2017). Democratizing digital learning: theorizing the fully online learning community model. International Journal of Educational Technology in Higher Education, 14(1), 1-16.

Collins, A., \& Halverson, R. (2018). Rethinking education in the age of technology: The digital revolution and schooling in America. Teachers College Press.

Dazki, E. (2015). Arsitektur Sistem e-Learning Berbasis Moodle Aptikom Open Education Architectural Framework. Indonesian Journal on Networking and Security. 5(2).

Dewanti, P., Santiari, N. P. L., \& Vedamurthi, K. V. (2021). E-Learning implementation in higher education in response to the covid-19 pandemic: a review. Journal of Science and Education (JSE), 2(1), 9-18.

Dwiyogo WD. Media pembelajaran. Malang: Wineka Media. 2013.

Garrison, D. R. (2011). E-learning in the 21st century: A framework for research and practice. Taylor \& Francis.

Goundar, S. (2011, December). What is the potential impact of using mobile devices in education. In Proceedings of SIG GlobDev Fourth Annual Workshop (Vol. 3, pp. 1-30).

International Association of Universities. (2020, August). Regional/National Perspectives on the Impact of COVID-19 on Higher Education, dari https://www.iau-aiu.net/IMG/pdf/iau_covid19_regional_perspectives_on_the_impact_of_covid-19_on_he_july_2020_.pdf

Luckin, R., Bligh, B., Manches, A., Ainsworth, S., Crook, C., \& Noss, R. (2012). Decoding learning: The proof, promise and potential of digital education.

Maphalala, M. C., \& Adigun, O. T. (2021). Academics' Experience of Implementing E-Learning in a South African Higher Education Institution. International Journal of Higher Education, 10(1), 1-13.

Meece, J. L., Blumenfeld, P. C., \& Hoyle, R. H. (1988). Students' goal orientations and cognitive engagement in classroom activities. Journal of educational psychology, 80(4), 514.

O'Brien, H. L., \& Toms, E. G. (2010). The development and evaluation of a survey to measure user engagement. Journal of the American Society for Information Science and Technology, 61(1), 50-69.

Okoli, C., \& Schabram, K. (2010). A guide to conducting a systematic literature review of information systems research.

Pate, S. S., \& Adams, M. (2013). The influence of social networking sites on buying behaviors of millennials. Atlantic Marketing Journal, 2(1), 7.

Ponciano, L., \& Brasileiro, F. (2015). Finding volunteers' engagement profiles in human computation for citizen science projects. arXiv preprint arXiv:1501.02134. 
Siemens, G., Gašević, D., \& Dawson, S. (2015). Preparing for the digital university: A review of the history and current state of distance, blended, and online learning.

Sousa, M. J., \& Rocha, Á. (2019). Strategic knowledge management in the digital age: JBR special issue editorial.

Unwin, T., Kleessen, B., Hollow, D., Williams, J. B., Oloo, L. M., Alwala, J., .. \& Muianga, X. (2010). Digital learning management systems in Africa: myths and realities. Open Learning: The Journal of Open, Distance and e-Learning, 25(1), 5-23.

Yulmezi, Y., \& Arifmiboy, A. (2021). The Level of Students Satisfaction on Learning English From Home at Mti Pasia Boarding School During Covid-19 Pandemic. Acitya: Journal of Teaching and Education, 3(2), 157-175.

Zboun, J. S., \& Farrah, M. (2021). Students' Perspectives of Online Language Learning During Corona Pandemic: Benefits and Challenges. Indonesian EFL Journal, 7(1), 13-20. 